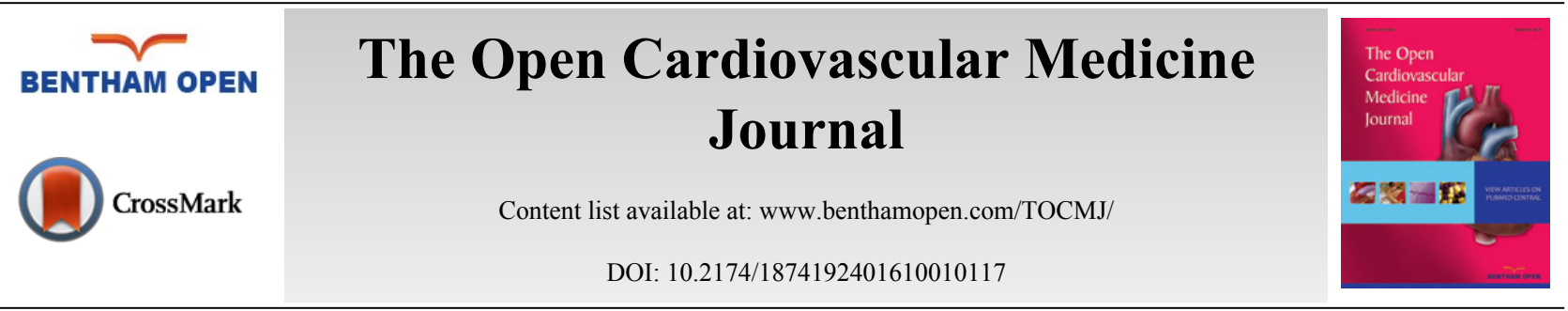

\title{
Association Between ACE Gene Polymorphism and QT Dispersion in Patients with Acute Myocardial Infarction
}

\author{
Zulkuf Karahan ${ }^{1}$, Murat Ugurlu, Berzal Ucaman ${ }^{1}$, Ali Veysel Ulug ${ }^{1}$, Ilyas Kaya ${ }^{1}, K_{\text {Kemal Cevik }}{ }^{1}$, \\ Mehmet Sahin Adiyaman ${ }^{1}$, Onder Oztürk ${ }^{1}$, Hikmet Iyem ${ }^{2, *}$ and Ferit Ozdemir ${ }^{2}$ \\ ${ }^{I}$ Gazi Yasargil Education and Research Hospital, Cardiology, Diyarbakir, Turkey \\ ${ }^{2}$ Gazi Yasargil Education and Research Hospital, Cardiovascular Surgery, Diyarbakir, Turkey
}

Received: November 22, 2015

Revised: February 2, 2016

Accepted: February 10, 2016

\section{Abstract:}

Background:

Angiotensin converting enzyme (ACE) gene polymorphism is associated with high renin-angiotensin system causing myocardial fibrosis and ventricular repolarization abnormality. Based on these findings, this study was designed to determine the association between ACE gene insertion/deletion (I/D) polymorphism and QT dispersion after acute myocardial infarction (MI).

\section{Objective and Methods:}

The study included 108 patients with acute MI. Blood samples were obtained from all the patients for genomic DNA analysis. ECGs were recorded at baseline and at the end of a 6-month follow up. The OT dispersion was manually calculated.

\section{Results:}

The mean age of the patients was $57.5 \pm 9.9$ years (ranging from 36 to 70). The patients with DD genotype showed longer QT dispersion than patients with II or DI genotype at the baseline, while at the end of the six-month follow up the patients with DI genotype showed longer QT dispersion than patients with DD or II genotypes. However, the magnitude of the QT dispersion prolongation was higher in patients carrying the ACE D allele than patients who were not carrying it, at baseline and at the end of six-month follow up $(52.5 \pm 2.6 \mathrm{msn} v s .47 .5 \pm 2.1 \mathrm{msn}$ at baseline, $57 \pm 3.2 \mathrm{msn} v s$. $53 \pm 2.6 \mathrm{msn}$ in months, $P: 0.428$ and $P: 0.613$, respectively).

\section{Conclusion:}

Carriers of the D allele of ACE gene I/D polymorphism may be associated with QT dispersion prolongation in patients with MI.An interaction of QT dispersion and ACE gene polymorphism may be associated with an elevation of serum type I-C terminal procollagen concentration, possibly leading to myocardial fibrosis, and increased action potential duration.

Keywords: ACE gene polymorphism, Coronary artery disease (CAD), Myocardial infarction, QT dispersion.

\section{INTRODUCTION}

Angiotensin converting enzyme (ACE) is a member of the renin-angiotensin system (RAS) which converts angiotensin I to angiotensin II. Angiotensin II regulates vascular tone and controls blood pressure. The RAS is affected in coronary artery disease $[1,2]$.

The ACE insertion/deletion (I/D) polymorphism that affects the levels of ACE serum activity involves 287 base

\footnotetext{
* Address correspondence to this author at the Gazi Yasargil Education and Research Hospital, Cardiovascular Surgery, Diyarbakir, Turkey; Email: hikmetiyem@gmail.com
} 
pairs in the intron 16 of the ACE gene [3]. ACE gene polymorphism determines the serum ACE levels. ACE levels are higher in the DD genotype than II and DI genotypes [4]. An I/D polymorphism of the ACE has been shown as a genetic marker for the risk of coronary artery disease (CAD) [5]. However, the D allele carriers are exposed to a higher level of angiotensin II, causing myocardial fibrosis and ventricular repolarization abnormalities, which plays an important role in the occurrence of cardiac arrhythmia [6].

QT dispersion has been associated with ventricular arrhythmias after MI and is considered an independent predictor of sudden cardiac death in MI [7]. The prolongation of QT dispersion is frequently associated with myocardial fibrosis severity after MI and is thought to show reduced ventricular repolarization homogeneity of a diseased heart [8].

The D allele carriers of ACE I/D gene polymorphism are shown to have higher levels of angiotensin II which is associated with poor prognosis after acute MI $[9,10]$. In the present study, we investigated the relationship between ACE I/D gene polymorphism and QT dispersion in patients with acute MI.

Table 1. Baseline demographic and echocardiographic variables of the patients.

\begin{tabular}{|c|c|c|c|c|}
\hline & DD genotype & II genotype & DI genotype & $\boldsymbol{P}$ \\
\hline Number of Patients & 29 & 20 & 59 & 0.22 \\
\hline Sex (Female/Male) & $3 / 26$ & $6 / 14$ & $12 / 47$ & 0.22 \\
\hline Mean Age (year) ( \pm SD) & $59.2 \pm 10$ & $58.2 \pm 11$ & $56.5 \pm 9.7$ & 0.42 \\
\hline Hypertension & 10 & 4 & 13 & 0.38 \\
\hline Diabetes Mellitus & 4 & 3 & 6 & 0.81 \\
\hline Smoking & 15 & 9 & 32 & 0.77 \\
\hline LV EF (\%) & $48.4 \pm 10$ & $49.4 \pm 8$ & $46.1 \pm 8.4$ & 0.72 \\
\hline LV end-diastolic diameter $(\mathrm{cm})$ & $4.9 \pm 0.4$ & $4.8 \pm 0.5$ & $4.7 \pm 0.4$ & 0.80 \\
\hline RV end-diastolic diameter $(\mathrm{cm})$ & $3.8 \pm 0.4$ & $3.6 \pm 0.3$ & $3.7 \pm 0.5$ & 0.78 \\
\hline
\end{tabular}

(LV EF, left ventricular ejection fraction)

\section{METHODS}

\section{Patients}

The study population consisted of 108 patients with acute MI (21 females and 87 males, with a mean age of 57.5 \pm 9.9 years) admitted to our clinic within six hours of the onset of chest pain. The diagnosis of MI was established according to the standard guidelines. Blood samples were obtained from all patients for genomic DNA analysis. The study was approved by the local Ethics Committee.

\section{Echocardiography}

The left and right ventricular end diastolic diameters were measured by echocardiography. The left ventricular ejection fraction was measured according to the modified Simpson method [11].

\section{Electrocardiography}

A standard 12 lead resting ECG was recorded at a paper speed of $25 \mathrm{~mm} / \mathrm{s}$ and a gain of $10 \mathrm{~mm} / \mathrm{mV}$ at baseline. All ECGs were manually analyzed by a single experienced cardiologist blinded to the clinical data. Patients with complete bundle branch block, second or third degree atrioventricular block were excluded. The QT was defined as the interval between the QRS onset and the end of the T wave. QT dispersion was calculated as the maximal QT interval minus the minimal QT interval of the 12 leads.

\section{Genetic Analysis}

The genomic of the patients was isolated from peripheral blood leukocytes. The ACE gene polymorphism was analyzed by polymerase chain reaction and reverse hybridization with CVD Strip Assay (Vienna, Austria).

\section{Statistics}

All data are expressed as mean \pm standard deviation (SD). Statistical analysis was performed using SSPS-18.0 (Statistical Package of Social Science version). Allele frequencies were deduced from the genotype frequencies. The differences in allele and genotype frequencies between the groups were evaluated by Mann-Whitney test and Kruskal Wallis test. Differences were considered significant for $P<0.05$. 


\section{RESULTS}

The study included 21 female and 87 male patients, and the age of patients at enrollment ranged from 36 to 70 years (mean $57.5 \pm 9.9$ years). In the 108 patients, $29(26.9 \%), 59(54.6 \%)$ and 20 (18.5\%) patients had the ACE DD, DI and II genotypes, respectively. Additionally, $88(81.5 \%)$ patients had the carriers of D allele gene. Table 1 presents the demographic and the echocardiographic data of all the patients. Moreover, there were no statistically significant differences between the three genotype groups and baseline characteristics.

Table 2. Association between ACE genotype and QT dispersion among the patients at baseline and after six months.

\begin{tabular}{|l|c|c|c|c|}
\hline & DD genotype & II genotype & DI genotype & $\boldsymbol{P}$ \\
\hline QT dispersion at baseline & $54.8 \pm 2.5$ & $47.5 \pm 2.1$ & $51.4 \pm 2.6$ & 0.611 \\
\hline QT dispersion after six months & $55.2 \pm 3.3$ & $53.1 \pm 2.5$ & $57 \pm 3.1$ & 0.842 \\
\hline
\end{tabular}

The patients with DD genotype showed longer QT dispersi on than patients with II or DI genotype at the baseline. Whereas, the patients with DI genotype showed longer QT dispersion than patients with DD or II genotype at the end of the six-month follow up (Table 2). On the other hand, the magnitude of the QT dispersion prolongation was higher in patients carrying the ACE D allele than not carrying the ACE D allele at baseline and the end of six-month follow up (Table 3). But, there were no statistically significant differences between the three genotype groups and the $\mathrm{D}$ allele.

Table 3. Comparison of QT dispersion in patients with/without $D$ allele carrier at baseline and after six months.

\begin{tabular}{|l|c|c|c|}
\hline & $\begin{array}{c}\text { D allele (+) } \\
\mathbf{n : 8 8}\end{array}$ & $\begin{array}{c}\text { D allele (-) } \\
\text { n:20 }\end{array}$ & $\boldsymbol{P}$ \\
\hline QT dispersion at baseline & $52.5 \pm 2.6$ & $47.5 \pm 2.1$ & 0.428 \\
\hline QT dispersion after six months & $57 \pm 3.2$ & $53 \pm 2.6$ & 0.613 \\
\hline
\end{tabular}

\section{DISCUSSION}

QT dispersion may contribute to an increased risk of ventricular arrhythmia and cardiac mortality. The prolongation of QT is frequently observed with age, medications, left ventricular hypertrophy and myocardial ischemia [12 - 14]. The left ventricular hypertrophy and myocardial infarction are known to reflect interstitial fibrosis that may result in prolonged action potential duration and QT dispersion [15]. The importance of QT dispersion is demonstrated in multiple studies [16]. In the present study, ACE I/D gene polymorphism may also affect QT dispersion in patients with diagnosed MI. We found that higher frequency of the D allele was also observed among the patients with acute MI. However, the patients with carrying the D allele had a higher prolongation of the QT dispersion at baseline and at the end of the six-month follow up.

Jeron et al., have found that the D allele carriers are associated with higher serum and myocardial tissue ACE levels than the II allele carriers after MI [17]. Another study has also observed that ACE D allele carriers have a big dispersion prolongation [6]. Moreover, Cambien showed that a higher level of ACE in plasma could be a risk factor for MI independent of the the ACE I/D gene polymorphism [18]. It was previously shown that ACE I/D gene polymorphism might affect cardiac dilatation and hypertrophy in MI or hypertensive patients $[10,19,20]$. The DD genotype was also associated with left ventricular hypertrophy [21]. In patients with previous MI, Nagashi et al. found a significantly higher LV endsystolic and enddiastolic dimension in the deletion group [22]. Previous studies on the ACE I/D gene polymorphism with CAD have shown that the DD genotype is associated with increased risk of CAD [5, 23, 24]. A recent meta-analysis indicated that the ACE I/D polymorphism is related to an increased risk of MI [25] . In addition, the ACE I/D gene polymorphism has been extensively studied in cardiovascular and cerebrovascular diseases, such as ischemic stroke and coronary artery disease [26, 27].

Moreover, the carriers of DD genotype and the D alleles may affect the severity of CAD whereas the II allele carriers may have a protective effect [28]. The ACE genotypes were shown to be associated with prolongation of QT dispersion in previous studies [17, 29]. Although the precise mechanism of ACE I/D gene polymorphism and the QT dispersion is not well clear, the ACE D allele may be associated with high serum type I-C terminal procollagen concentration leading to myocardial fibrosis which increased action potential duration in some cardiac areas [30]. The present study indicates that the carriers of the D allele may affect the QT dispersion in patients with acute MI. But, there were no statistically significant differences between the three genotype groups and the $\mathrm{D}$ allele.

A limitation of the present study was the lack of long term follow up on the risk of cardiac arrhythmia and cardiac arrest and also relatively small sample size. In addition, the effects of gene-gene and gene-environment interactions 
were not addressed in this study. Moreover, ACE plasma level was not measured, and it was influenced by many factors.

\section{CONCLUSION}

In patients with acute myocardial infarction, the carriers of D allele of ACE I/D gene polymorphism may be affected with the QT dispersion prolongation. Further studies are needed to support our results.

\section{CONFLICT OF INTEREST}

The authors confirm that this article contains no conflict of interest.

\section{ACKNOWLEDGEMENTS}

This research received no specific grant from any funding agency in the public, commercial, or not-for-profit sectors.

\section{REFERENCES}

[1] Soldner A, Spahn-Langguth H, Mutschler E. The renin-angiotensin-aldosterone system: focus on its distinct role in arterial hypertension and its various inhibitors as a therapeutic strategy to effectively lower blood pressure. Pharmazie 1996; 51(11): 783-99. [PMID: 8985974]

[2] Ferrario CM, Strawn WB. Role of the renin-angiotensin-aldosterone system and proinflammatory mediators in cardiovascular disease. Am J Cardiol 2006; 98(1): 121-8.

[http://dx.doi.org/10.1016/j.amjcard.2006.01.059] [PMID: 16784934]

[3] Harrap SB, Davidson HR, Connor JM, et al. The angiotensin I converting enzyme gene and predisposition to high blood pressure. Hypertension 1993; 21(4): 455-60. [http://dx.doi.org/10.1161/01.HYP.21.4.455] [PMID: 8384602]

[4] Rigat B, Hubert C, Alhenc-Gelas F, Cambien F, Corvol P, Soubrier F. An insertion/deletion polymorphism in the angiotensin I-converting enzyme gene accounting for half the variance of serum enzyme levels. J Clin Invest 1990; 86(4): 1343-6. [http://dx.doi.org/10.1172/JCI114844] [PMID: 1976655]

[5] Cambien F, Poirier O, Lecerf L, et al. Deletion polymorphism in the gene for angiotensin-converting enzyme is a potent risk factor for myocardial infarction. Nature 1992; 359(6396): 641-4. [http://dx.doi.org/10.1038/359641a0] [PMID: 1328889]

[6] Lin TH, Chiu HC, Su HM, et al. D-allele of ACE polymorphism is associated with increased magnitude of QT dispersion prolongation in elderly Chinese: 4-year follow-up study. Circ J 2007; 71(1): 39-45. [http://dx.doi.org/10.1253/circj.71.39] [PMID: 17186976]

[7] Elming H, Holm E, Jun L, et al. The prognostic value of the QT interval and QT interval dispersion in all-cause and cardiac mortality and morbidity in a population of Danish citizens. Eur Heart J 1998; 19(9): 1391-400.

[http://dx.doi.org/10.1053/euhj.1998.1094] [PMID: 9792266]

[8] Day CP, McComb JM, Campbell RW. QT dispersion: an indication of arrhythmia risk in patients with long QT intervals. Br Heart J 1990; 63(6): 342-4.

[http://dx.doi.org/10.1136/hrt.63.6.342] [PMID: 2375895]

[9] Oosterga M, Voors AA, de Kam PJ, et al. Plasma angiotensin-converting enzyme activity and left ventricular dilation after myocardial infarction. Circulation 1997; 95(12): 2607-9. [http://dx.doi.org/10.1161/01.CIR.95.12.2607] [PMID: 9193426]

[10] Pinto YM, van Gilst WH, Kingma JH, Schunkert H. Deletion-type allele of the angiotensin-converting enzyme gene is associated with progressive ventricular dilation after anterior myocardial infarction. J Am Coll Cardiol 1995; 25(7): 1622-6. [http://dx.doi.org/10.1016/0735-1097(95)00090-Q] [PMID: 7759715]

[11] Paulus WJ, Tschöpe C, Sanderson JE, et al. How to diagnose diastolic heart failure: a consensus statement on the diagnosis of heart failure with normal left ventricular ejection fraction by the Heart Failure and Echocardiography Associations of the European Society of Cardiology. Eur Heart J 2007; 28(20): 2539-50.

[http://dx.doi.org/10.1093/eurheartj/ehm037] [PMID: 17428822]

[12] Haraguchi Y, Yoshinaga M, Sarantuya J, et al. Interval representative of transmural dispersion of repolarization in children and young adolescents with congenital long QT syndrome. Circ J 2005; 69(1): 78-82. [http://dx.doi.org/10.1253/circj.69.78] [PMID: 15635208]

[13] Higham PD, Furniss SS, Campbell RW. QT dispersion and components of the QT interval in ischaemia and infarction. Br Heart J 1995; 73(1): 32-6. [http://dx.doi.org/10.1136/hrt.73.1.32] [PMID: 7888257]

[14] Oikarinen L, Nieminen MS, Viitasalo M, et al. Relation of QT interval and QT dispersion to echocardiographic left ventricular hypertrophy 
and geometric pattern in hypertensive patients. The LIFE study. The Losartan Intervention For Endpoint Reduction. J Hypertens 2001; 19(10): 1883-91.

[http://dx.doi.org/10.1097/00004872-200110000-00025] [PMID: 11593111]

[15] Bikkina M, Larson MG, Levy D. Asymptomatic ventricular arrhythmias and mortality risk in subjects with left ventricular hypertrophy. J Am Coll Cardiol 1993; 22(4): 1111-6.

[http://dx.doi.org/10.1016/0735-1097(93)90424-Y] [PMID: 8409049]

[16] Okin PM, Devereux RB, Howard BV, Fabsitz RR, Lee ET, Welty TK. Assessment of QT interval and QT dispersion for prediction of allcause and cardiovascular mortality in American Indians: The Strong Heart Study. Circulation 2000; 101(1): 61-6. [http://dx.doi.org/10.1161/01.CIR.101.1.61] [PMID: 10618305]

[17] Jeron A, Hengstenberg C, Engel S, et al. The D-allele of the ACE polymorphism is related to increased QT dispersion in 609 patients after myocardial infarction. Eur Heart J 2001; 22(8): 663-8. [http://dx.doi.org/10.1053/euhj.2000.2297] [PMID: 11286523]

[18] Cambien F, Costerousse O, Tiret L, et al. Plasma level and gene polymorphism of angiotensin-converting enzyme in relation to myocardial infarction. Circulation 1994; 90(2): 669-76.

[http://dx.doi.org/10.1161/01.CIR.90.2.669] [PMID: 8044936]

[19] Danser AH, Schalekamp MA, Bax WA, et al. Angiotensin-converting enzyme in the human heart. Effect of the deletion/insertion polymorphism. Circulation 1995; 92(6): 1387-8. [http://dx.doi.org/10.1161/01.CIR.92.6.1387] [PMID: 7664416]

[20] Perticone F, Maio R, Cosco C, et al. Hypertensive left ventricular remodeling and ACE-gene polymorphism. Cardiovasc Res 1999; 43(1): 192-9. [http://dx.doi.org/10.1016/S0008-6363(99)00055-3] [PMID: 10536704]

[21] Schunkert H, Hense HW, Holmer SR, et al. Association between a deletion polymorphism of the angiotensin-converting-enzyme gene and left ventricular hypertrophy. N Engl J Med 1994; 330(23): 1634-8.

[http://dx.doi.org/10.1056/NEJM199406093302302] [PMID: 8177269]

[22] Nagashima J, Musha H, So T, Kunishima T, Nobuoka S, Murayama M. Effect of angiotensin-converting enzyme gene polymorphism on left ventricular remodeling after anteroseptal infarction. Clin Cardiol 1999; 22(9): 587-90. [http://dx.doi.org/10.1002/clc.4960220909] [PMID: 10486698]

[23] Acarturk E, Attila G, Bozkurt A, Akpinar O, Matyar S, Seydaoglu G. Insertion/deletion polymorphism of the angiotensin converting enzyme gene in coronary artery disease in southern Turkey. J Biochem Mol Biol 2005; 38(4): 486-90. [http://dx.doi.org/10.5483/BMBRep.2005.38.4.486] [PMID: 16053717]

[24] Wang XL, McCredie RM, Wilcken DE. Genotype distribution of ACE polymorphism in Australian healthy and coronary populations and relevance to myocardial infarction and coronary artery disease. Arterioscler Thromb Vasc Biol 1996; 16: 115-9. [http://dx.doi.org/10.1161/01.ATV.16.1.115] [PMID: 8548410]

[25] Chen Y, Dong S, He M, Qi T, Zhu W. Angiotensin-converting enzyme insertion/deletion polymorphism and risk of myocardial infarction in an updated meta-analysis based on 34993 participants. Gene 2013; 522(2): 196-205. [http://dx.doi.org/10.1016/j.gene.2013.03.076] [PMID: 23566835]

[26] Gao X, Yang H, ZhiPing T. Association studies of genetic polymorphism, environmental factors and their interaction in ischemic stroke. Neurosci Lett 2006; 398(3): 172-7.

[http://dx.doi.org/10.1016/j.neulet.2005.12.078] [PMID: 16443328]

[27] Vaisi-Raygani A, Ghaneialvar H, Rahimi Z, et al. The angiotensin converting enzyme D allele is an independent risk factor for early onset coronary artery disease. Clin Biochem 2010; 43(15): 1189-94. [http://dx.doi.org/10.1016/j.clinbiochem.2010.07.010] [PMID: 20655894]

[28] Guney AI, Ergec D, Kıraç D, et al. Effects of ACE polymorphisms and other risk factors on the severity of coronary artery disease. Genet Mol Res 2013; 12(4): 6895-906. [http://dx.doi.org/10.4238/2013.December.19.8] [PMID: 24391037]

[29] Takahashi T, Ueno H, Yasumoto K, et al. Angiotensin-converting enzyme-gene polymorphism is associated with collagen I synthesis and QT dispersion in essential hypertension. J Hypertens 2003; 21(5): 985-91. [http://dx.doi.org/10.1097/00004872-200305000-00024] [PMID: 12714874]

[30] Savelieva I, Camm AJ, Malik M. QT dispersion should be adjusted for age: Observations from 1096 normal subjects. J Am Coll Cardiol $1993 ; 33$.

(C) Karahan et al.; Licensee Bentham Open.

This is an open access article licensed under the terms of the Creative Commons Attribution-Non-Commercial 4.0 International Public License (CC BY-NC 4.0) (https://creativecommons.org/licenses/by-nc/4.0/legalcode), which permits unrestricted, non-commercial use, distribution and reproduction in any medium, provided the work is properly cited. 